\title{
Poetyka widzenia Joanny ślósarskiej, teoria widzenia Władystawa Strzemińskiego, teoria języka Ronalda W. Langackera
}

Wedtug oficjalnych informacji podanych na stronie internetowej Iranki Mahdieh Gholami, międzynarodowego eksperta w dziedzinie zarządzania zasobami ludzkimi, jej hobby stanowią podróże i malarstwo. Zamiłowanie do podróżowania wyjaśnia zapewne, dlaczego postanowiła ona osiąść w Warszawie i uczyć się polskiego, a zamiłowanie do malarstwa - dlaczego ucząc się egzotycznego dla siebie języka, przygląda się relacji obrazu i słowa. Gdyby problem Mahdieh Gholami przeanalizować w kategoriach językoznawstwa kognitywnego, powiedziałoby się, że na obecnym etapie nauki nie potrafi ona jeszcze w słownym opisie obrazka zejść poniżej poziomu definiowanego jako podstawowy; w nagromadzonych zasobach leksykalnych brak jej (jeszcze) leksemów z niższych i wyższych poziomów organizacji leksykonu, czyli - w tym właśnie zakresie - językowej kompetencji. Innymi słowy, widzieć nie znaczy dla niej (jeszcze) umieć powiedzieć.

Obie umiejętności w stopniu najwyższym łączyła w sobie Joanna Ślósarska - malarka i poetka, której pamięci poświęcam niniejszy esej. Jej postać zamierzam zestawić z postacią innego twórcy, równie wybitnego i wszechstronnego - malarza i teoretyka sztuki Władysława Strzemińskiego. Za materiał badawczy posłużą mi wybrane wiersze Ślósarskiej, które skonfrontuję z fragmentami głównego niemalarskiego dzieła Strzemińskiego - monografii zatytułowanej Teoria widzenia, wydanej po raz pierwszy w 1958 roku i wznowionej w roku 2016. Wreszcie obie wizje - poetycką i malarską - spróbuję odnieść do wybranych tez językoznawstwa kognitywnego, sformułowanych przez jego twórcę - amerykańskiego językoznawcę Ronalda W. Langackera. 
Władysław Strzemiński był przede wszystkim malarzem, ale sposób, w jaki o malarstwie - własnym i cudzym - pisał w swoich tekstach, świadczy o świadomości istnienia ścisłych powiązań między słowem i obrazem. Myśl przewodnia jego książki zawiera się w stwierdzeniu, że należy „najpierw poznać istotę widzenia, a potem mówić o malarstwie” (Strzemiński, 2016: 301). Czytając wiersze Ślósarskiej, należałoby dodać: i o poezji. Nie jest też zapewne przypadkiem, że obszerną przedmowę do Teorii widzenia napisał Julian Przyboś - poeta i tłumacz, wirtuoz słowa, wieloletni mentor i przyjaciel Strzemińskiego (Przyboś, 2016). Sam Strzemiński natomiast mógłby zapewne napisać przedmowę do któregoś poetyckiego tomiku Ślósarskiej (a może do wszystkich ośmiu?). W jej wierszach pojawia się bowiem fundamentalna dla rozważań Strzemińskiego opozycja między „dwoma realizmami”: realizmem rzeczy (czyli „fikcją jednego spojrzenia” - Strzemiński, 2016: 301) i realizmem procesu wzrokowego (wynikającym z tezy, że „każde spojrzenie wnosi inne określenia formy" - Strzemiński, 2016: 303). Wydaje się, że - podobnie jak Strzemiński - poetka odrzuca realizm pierwszy i opowiada się za drugim. Językoznawcy kognitywnemu nie wypada w tym miejscu nie zwrócić uwagi czytelnika na fakt, że jest to także podstawowa opozycja rządząca systemami gramatycznymi języków naturalnych, czyli dychotomiczny kontrast między rzeczami i procesami (relacjami) (Langacker, 2009).

Dla Strzemińskiego ,jedno spojrzenie”, implikujące jeden tylko punkt widzenia, nie jest w stanie obiektywnie oddać istoty widzianego przedmiotu, ponieważ jego obraz nigdy nie jest obiektywny; sztuka - podobnie zresztą jak słowo - opisuje świat nie takim, jakim jest, ale takim, jakim się wydaje danemu obserwatorowi w określonym kontekście wyznaczonym przez parametry przestrzenne, czasowe, kulturowe i pragmatyczne. Realizm rzeczy jest więc fikcją: przedmiot widziany, zarówno oculis corporis (oczyma ciała), jak i oculis mentis (oczyma duszy - wyobraźni), jest nieuchronnie obciążony subiektywizmem, fenomenologicznym „czynnikiem ludzkim”. Ilustracją tej tezy mógłby z powodzeniem być wiersz Joanny Ślósarskiej, któremu poetka nadała wiele mówiący tytuł Za plecami angielskich metafizyków (2016b: 153):

nie wiem

jak oni patrzyli że widzieli krople

ja widzę

drzazgi deszczu

drzazgi krwi

drzazgi soku

i białe drzazgi łez. 
W teorii Strzemińskiego „fikcja jednego spojrzenia” odpowiada w malarstwie perspektywie zbieżnej, która zakłada nieruchomość spojrzenia, patrzenie bez „przerw i przeskoków”. Zdaniem autora Teorii widzenia „perspektywa zbieżna jest zgodna z geometrią, lecz nie zgadza się z fizjologią naszego widzenia" (Strzemiński, 2016: 299). W przytoczonym wyżej wierszu „angielscy metafizycy” widzą deszcz, tak jak widziałby go malarz przyjmujący umowne założenie, że „jednym spojrzeniem możemy w pełni ogarnąć całą przestrzeń przed nami i zobaczyć ją całą, we wszystkich częściach z jednakową dokładnością" (Strzemiński, 2016: 299). Odwołując się ponownie do terminologii Strzemińskiego, to właśnie robią "angielscy metafizycy”, stawiając „prawdę przedmiotu” ponad „prawdą widzenia”. W wierszu Ślósarskiej (która się angielskim metafizykom dziwi) opis deszczu wyraża natomiast impresjonistyczną „prawdę widzenia”: jest „syntezą wielu spojrzeń” (Strzemiński, 2016: 303), nakładających się na siebie i nawzajem się przenikających.

Mówiąc o widzeniu jako procesie, Strzemiński odwołuje się do fizjologii ludzkiego oka: wzrok dostosowuje się do odległości dzielącej oko od przedmiotu oglądu, a samo widzenie dokonuje się jako seria „przeskoków” wzroku - we wszystkich kierunkach - do kolejnych wyróżnianych punktów, które skupiają na sobie uwagę patrzącego. I tym razem nie sposób nie dostrzec analogii tego opisu do proponowanego przez językoznawców kognitywnych opisu zależności między procesami postrzegania rzeczywistości, tworzenia konceptualizacji i budowania na ich podstawie językowej ekspresji. Szczególnie bliskie teorii widzenia Strzemińskiego są postulowane w Langackerowskiej teorii języka i gramatyki wymiary obrazowania, stanowiące parametry językowych wyborów dokonywanych ze względu na charakter przekazywanego obrazu. Wymiary obrazowania to punkt widzenia i perspektywa, wzajemny układ figury i tła, selekcja elementów o różnym stopniu wyrazistości i poziom uszczegółowienia.

Dla językoznawcy (por. np. Langacker, 2009: rozdz. 3) cechy widzenia oculis corporis stanowią podstawę metafory pozwalającej na opis sposobów językowego wyrażania wyobrażeń: konceptualizacji, które mają w systemie języka kształt obrazów oglądanych oculis mentis. Natomiast w teorii Strzemińskiego odwołanie do fizjologicznych aspektów procesu widzenia kształtuje interpretację obrazu malarskiego; analiza perspektywy, którą Strzemiński nazywa „przestrzenną” i uznaje za cechę definicyjną impresjonizmu, przebiega wprawdzie w kierunku odwrotnym do kierunku procesów interpretacyjnych, ale w swojej istocie mogłaby się z powodzeniem znaleźć w podręczniku gramatyki kognitywnej. Poecie natomiast dostępne środki wyrazu pozwalają na odmalowanie obrazu, który w malarstwie odpowiadałby impresjonizmowi (tak jak go definiuje Strzemiński w swojej Teorii widzenia). 
Fragment wiersza Po drodze Joanny Ślósarskiej (2016b: 108) jest takim właśnie impresjonistycznym obrazem:

anioł w dżinsowej kurtce

idzie po falach

niebieski błysk mokrych piór

Uwagę patrzącego przykuwa (przede wszystkim, a może nawet tylko) dżinsowa kurtka anioła (psycholog powiedziałby zapewne, że to dlatego, iż jest to strój u anioła niezwyczajny); anioł idzie po falach i najpewniej się od patrzącego oddala, skoro na drugim obrazie, na dalszym planie, pozostał po nim już tylko błysk: nieokreślony i pozaczasowy (brak czasownika!) ruch czegoś, co jest (zapewne) piórami (bo anielskie skrzydła), mokrymi (bo fale i błysk kropel wody). Tak więc w tym króciutkim fragmencie znalazły się dwa różne plany przestrzenne. Na planie bliższym portretowana postać jest interpretowana jako anioł (w dżinsowej kurtce - a może to jednak widziane $z$ daleka anielskie skrzydta?), na planie dalszym obraz jest zamazany - zostaje tylko pozbawiony ostrego konturu „niebieski błysk”. Poetycki portret anioła byłby zapewne dla Strzemińskiego przykładem „perspektywy ruchomego spojrzenia”, śledzenia postaci wzrokiem, który nie potrafi dość szybko przestawić się na ostre widzenie dalekich planów. Cytując autora Teorii widzenia: „,plany przestrzenne należące do innych odległości stapiają się razem w dość jednolitą płaszczyznę barwną, nasyconą przestrzenią o kolorze sprowadzonym do ich wspólnego mianownika" (Strzemiński, 2016: 306) - niebieskiej barwy dżinsu, skrzydeł i fal. Poetka - a także jej czytelnik - może, jak Mahdieh Gholami, „zrozumieć obrazek, ale nie umie opisać szczegółów”. Używając terminologii zaczerpniętej z Langackerowskiej teorii gramatyki, odmalowany w omawianym fragmencie wiersza obraz cechuje niski poziom uszczegółowienia: z wyjątkiem jednego z elementów, na którym skupia się uwaga patrzącego, przypisując mu większą wyrazistość, przedmioty są tylko naszkicowane, widziane nieostro.

Ideę perspektywy ruchomego spojrzenia przechodzącego z jednego planu przestrzennego do innego doskonale ilustruje kolejny wiersz ślósarskiej, noszący charakterystyczny dla jej strategii poetyckiej tytuł Drobnowidło $i$ Wielkowidto (Ślósarska, 2016b: 68):

daję błękitnym koniom

szorstką trawę mroku

ale

patrzę teraz przez Drobnowidło 
gdy

podniosę głowę

zobaczę zapewne

niebieskie

tylko kropki

na szarej kartce

gdy zasnę

może zobaczę

przez Wielkowidło

błękitne konie na uprzężach słońca

zobaczę sobie

moje anioły

jak karmią

błękitne konie

szorstką trawą chmur

„Drobnowidło” jest, jak wiadomo, starą, dziś już nieużywaną nazwą mikroskopu. W wierszu Ślósarskiej to urządzenie pozwala powiększyć w (szarym) mroku obraz (błękitnych) koni, które na innym planie przestrzennym - widziane gołym okiem („gdy podniosę głowę” znad drobnowidta ku niebu) - stają się „niebieskimi tylko kropkami na szarej kartce". Jakie są więc właściwie te konie? Ogląda się je przez „wielkowidło”. Logicznie rzecz biorąc, ten stworzony przez twórczą wyobraźnię przyrząd powinien wielkie obiekty pomniejszać. Tymczasem w cytowanym wierszu „wielkowidło” jawi się jako urządzenie służące do powiększania, ale i do wyostrzania obrazu: „niebieskie kropki” to teraz „błękitne konie”, zaprzęgnięte w słoneczne promienie, a "szara kartka” to łąka pokryta "trawą chmur”. Można by zatem powiedzieć, że „drobnowidło” i „wielkowidło” konstytuują metaforę perspektywy ruchomego spojrzenia (według Strzemińskiego), ilustrując tym samym wymiar uszczegółowienia (według Langackera), który szczegółowość obrazu uzależnia od przystosowania wzroku do „widzenia na daną, określoną odległość" (Strzemiński, 2016: 306), czyli od tego, „z jakiej odległości prowadzimy ogląd” (Langacker, 2009: 85).

Zasada perspektywy ruchomego spojrzenia, u Strzemińskiego stanowiąca fundament teorii widzenia, znajduje zatem odbicie w teorii gramatyki Langackera. Strzemiński twierdzi, że widzenie musi być procesem - a więc ruchem spojrzenia, bo „jednym spojrzeniem widzimy tylko jeden konkretny wycinek przestrzeni należący do jednego planu przestrzennego" (Strzemiński, 2016: 306). Natomiast 
Langacker uważa, że na kształt sceny w wyrażeniu językowym zasadniczy wpływ wywiera abstrakcyjny (subiektywny) ruch konceptualizatora (Langacker, 1991: 160).

W Drobnowidle $i$ Wielkowidle spojrzenie - wspomagane dwoma tytułowymi instrumentami - wędruje od szkiełka mikroskopu ku niebu i z powrotem. Natomiast w wierszu bez tytułu, który cytuję poniżej (Ślósarska, 1999: 18), perspektywa ruchomego spojrzenia wspomagana jest semantyką leksykalną (a więc jest jeszcze bliższa teorii Langackera):

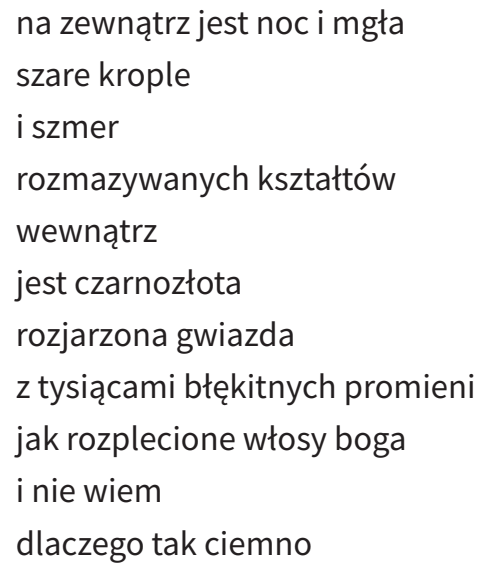

Dwa plany przestrzenne wiersza są ukształtowane przez dwa elementy o przeciwnym znaczeniu: frazę przyimkową "na zewnątrz” i przyimek „wewnątrz”. Na bezksztattnym tle „nocy i mgły”, w terminologii Langackera niewykonturowanym, u Strzemińskiego stanowiącym „dość jednolite płaszczyzny”, uwagę patrzącego przyciągają krople - wprawdzie szare, lecz policzalne, wykonturowane, a przez to łatwiej wyodrębniane z tła. Inne kształty są „,rozmazywane” przez deszcz (synestezyjnie desygnowany onomatopeicznym rzeczownikiem „szmer”). Obrazu dopełnia scena „wewnątrz”, gdzie uwagę przyciąga wyraźny kształt i kolor „gwiazdy” z „tysiącami błękitnych promieni”. Jednak mimo pozornej odrębności elementów rejestrowanych przez ruchome spojrzenie "na zewnątrz" $i$ „wewnątrz” to w gruncie rzeczy jeden obraz, połączony przysłówkiem „ciemno”, który wyznacza „przestrzeń otaczającą wszystkie widziane [...] przedmioty” (Strzemiński, 2016: 261). Wydaje się, że właśnie ta semantyczna klamra buduje znaczenie wiersza.

Perspektywę ruchomego spojrzenia można też zapewne uznać za mechanizm warunkujący rozumienie tekstu (a być może i obrazu), polegający na przyjmowaniu i odrzucaniu kolejnych interpretacji obrazu nieostrego, a więc niejednoznacznego. Można to zaobserwować na przykładzie kolejnego wiersza Joanny Ślósarskiej (1996: 16): 
ach to nie był wcale kwiat

ani nawet jaskółka

to nie było też cieniem

ani echem

ach to nie był wcale kwiat

to zalśniło nagle

w czuprynie chmury

jak spinka która nigdy niczego nie

spina

Widziany obraz jest na tyle niewyraźny (zapewne oglądany z odległości, na którą wzrok nie jest „nastawiony”), że nie daje się łatwo zidentyfikować. Nie jest to ani wykonturowany przedmiot (nieruchomy kwiat lub lecąca jaskółka), ani niewykonturowana Langackerowska „substancja” (por. np. Langacker, 2009: 180 i nast.), czyli cień, ani wreszcie wrażenie słuchowe, zapożyczenie z innej domeny, a może synestezja - pogłos jako metafora „po-widoku” (czy też, jak chce Strzemiński, „powidoku”, czyli „śladu przedmiotu o tym samym kształcie” - Strzemiński, 2016: 88). „To” przyciągnęło wzrok na czas zbyt krótki, żeby się je dało zidentyfikować („zalśniło nagle”) - jest zatem określane „przez eliminację” i „ex post” interpretowane jak oglądany na wystawie obraz. Jednak tym razem słowo może więcej: aspekt dokonany czasownika „zalśnić” i przysłówek „nagle” konstytuują przestrzeń czasową, podkreślając czasowy wymiar procesu widzenia i zdolność ruchomego spojrzenia do przebiegania nie tylko poszczególnych partii obrazów malarskich, widzianych oculis corporis, ale także przywoływanych przez nie obrazów mentalnych, oglądanych oculis mentis. Z „syntezy wielu spojrzeń”, o której mówił Strzemiński (2016: 303), wyłania się obraz „tego” czegoś, co ma jednocześnie cechy kwiatu, jaskółki, cienia i echa.

W wyrażeniach językowych - a w szczególności w wyrażaniu znaczeń za pomocą języka nazywanego potocznie poetyckim - przyjmowanie perspektywy ruchomego spojrzenia jest podstawową strategią. W systemie języka służą jej określone środki gramatyczne; w przypadku planu czasowego są to oczywiście głównie osobowe formy czasownika - czas, tryb i aspekt. O wierszu Ślósarskiej zatytułowanym Bez czasowników pisałam obszerniej w innym miejscu (Tabakowska, 2018). Tu skupię się jedynie na tych aspektach analizy, które wydają się istotne z perspektywy niniejszych rozważań. 
pierwszy przez światło dzikość mokre przez liście

żywe krawędź cień róża

rękawiczka płatki młodość łodyga

płomień poranek przez

słońce ostatni rosa czerwień skóra

ciernie dzikich róż

przez rękawiczkę

przez skórę

mokre czerwone światło płatków

$z$ rosą

młode słońce w płomieniach łodyg

pierwszy i ostatni poranek

na krawędziach żywych liści

Mimo że, zgodnie z tytułem, w wierszu brak czasowników, jest on pełen ruchu i dynamiki. Wrażenie ruchu konstytuują wyrażenia przyimkowe z przyimkiem „przez”, wyrażającym przechodzenie, przenikanie, a więc złożony z następujących po sobie etapów proces. Jednak nie tylko. Sekwencja rzeczowników odnoszących się do bytów wykonturowanych (czyli Langackerowskich „rzeczy” - „liście”, „krawędź”, „róża”, „rękawiczka”, „płatki”, „łodyga”, „słońce”, „skóra”) lub o rozmytych granicach („niewykonturowanych” Langackerowskich substancji, konkretnych - „światło”, „cień”, „płomien”, „poranek”, „rosa”) albo wreszcie abstrakcyjnych („dzikość”, „młodość” „czerwień”) wydaje się odbiciem procesu widzenia, stanowiącego serię „przerw i przeskoków”, o których pisał Strzemiński. Spojrzenie „przeskakuje” z jednego elementu na inny. Analizując wiersz Bez czasowników, we wspomnianym wyżej eseju (Tabakowska, w druku) pisałam, że wszystkie pojawiające się w pierwszej zwrotce odniesienia do rzeczy powracają w drugiej (wyjątek stanowi wyraz „cień”, któremu w drugiej zwrotce opowiada niemal homofoniczny wyraz „ciernie”). Nie są to jednak powtórzenia dosłowne.

[...] pozbawione konturu przestrzennego światło uzyskuje w drugim użyciu kontur nadany przez połączenie z wykonturowanymi płatkami, podobnie jak początkowo niewykonturowana dzikość staje się cechą posiadających kontur róż. Młodość z pierwszej zwrotki w zwrotce drugiej staje się cechą przysługującą rzeczom, nadając w ten sposób słońcu kontur i ujednoznaczniając konceptualizację. Pozbawiony wyraźnego konturu płomień z pierwszej zwrotki w drugiej przejmuje kontur od wykonturowanych łodyg. Wreszcie niewykonturowana czerwień staje się przymiotem 
światła płatków, niejako przejmując od światła kontur nadany przez ostro wykonturowane płatki (Tabakowska, w druku).

Ta seria zmian - przebiegających jednakowo i w tym samym kierunku - sygnalizuje mentalne zbliżanie się obserwatora do obserwowanej sceny; pojawianie się ostrych konturów oddaje przejście od „niewyraźnego” do „wyraźnego”, od obiektu rysującego się niewyraźnie w oddali do narysowanego ostrą kreską zbliżenia. „W efekcie tej zmiany dystansu [obraz] konkretyzuje się i nabiera wyrazistości” (Tabakowska, w druku). Można oczywiście szczegółowo przeanalizować językowe środki, które służą do osiągnięcia tego efektu, i zapewne najprecyzyjniej można to zrobić, wykorzystując instrumentarium wypracowane przez Langackera (co staram się wykazać w cytowanym artykule). W tym miejscu interesuje nas jednak przede wszystkim zbieżność obrazu stworzonego przez poetkę z obrazem będącym dziełem malarza.

Lektura teorii widzenia Strzemińskiego podpowiada, że wiersz Bez czasowników jest obrazem impresjonisty. Jest wierszem lirycznym, podobnie jak liryczne i impresjonistyczne są obrazy pędzla Ślósarskiej.

Strzemiński określa liryzm jako „naszą reakcję na proces widzenia świata” (Strzemiński, 2016: 303). Tak zdefiniowany jest on atrybutem zarówno malarstwa, jak i poezji Joanny Ślósarskiej, ale teoretycy języka byliby zapewne także skłonni przyjąć, że jest to cecha większości tego, co każdy z nas, w każdym języku, wypowiada w aktach codziennej komunikacji. W określaniu granic liryzmu Strzemiński jest optymistą: „na razie przynajmniej nie ma granic dla tego realizmu wielostronnego i lirycznego, będącego naszą wypowiedzią o tym, co odczuwamy, i naszą odpowiedzią na to, co widzimy przed sobą" (Strzemiński, 2016: 303).

Dla Strzemińskiego realizm procesu wzrokowego - w odróżnieniu od realizmu rzeczy - jest cechą sztuki współczesnej (XX wieku), wypracowaną w efekcie chronologicznego (historycznego) procesu rozwoju cywilizacji i kultur. Jest emanacją „prawdy widzenia”. Szukający swojej prawdy językoznawca sięga do innych źródeł. Znajduje je w tezie, którą w epoce narodzin językoznawstwa kognitywnego jeden z jego twórców, George Lakoff, nazwał „zobowiązaniem do kognitywizmu”. Głosi ona, że badacz języka musi reagować na wyniki badań uzyskiwanych przez przedstawicieli różnych dyscyplin. Wśród nich Lakoff wymienia psychologię poznawczą i rozwojową, antropologię, nauki kognitywne i koneksjonizm (Lakoff, 1989: 3), twierdząc, że zbieżność analiz przeprowadzanych przez przedstawicieli różnych dziedzin pozwala wierzyć, iż - rozpatrywane razem - zbliżają one badaczy do odkrycia prawdy. 


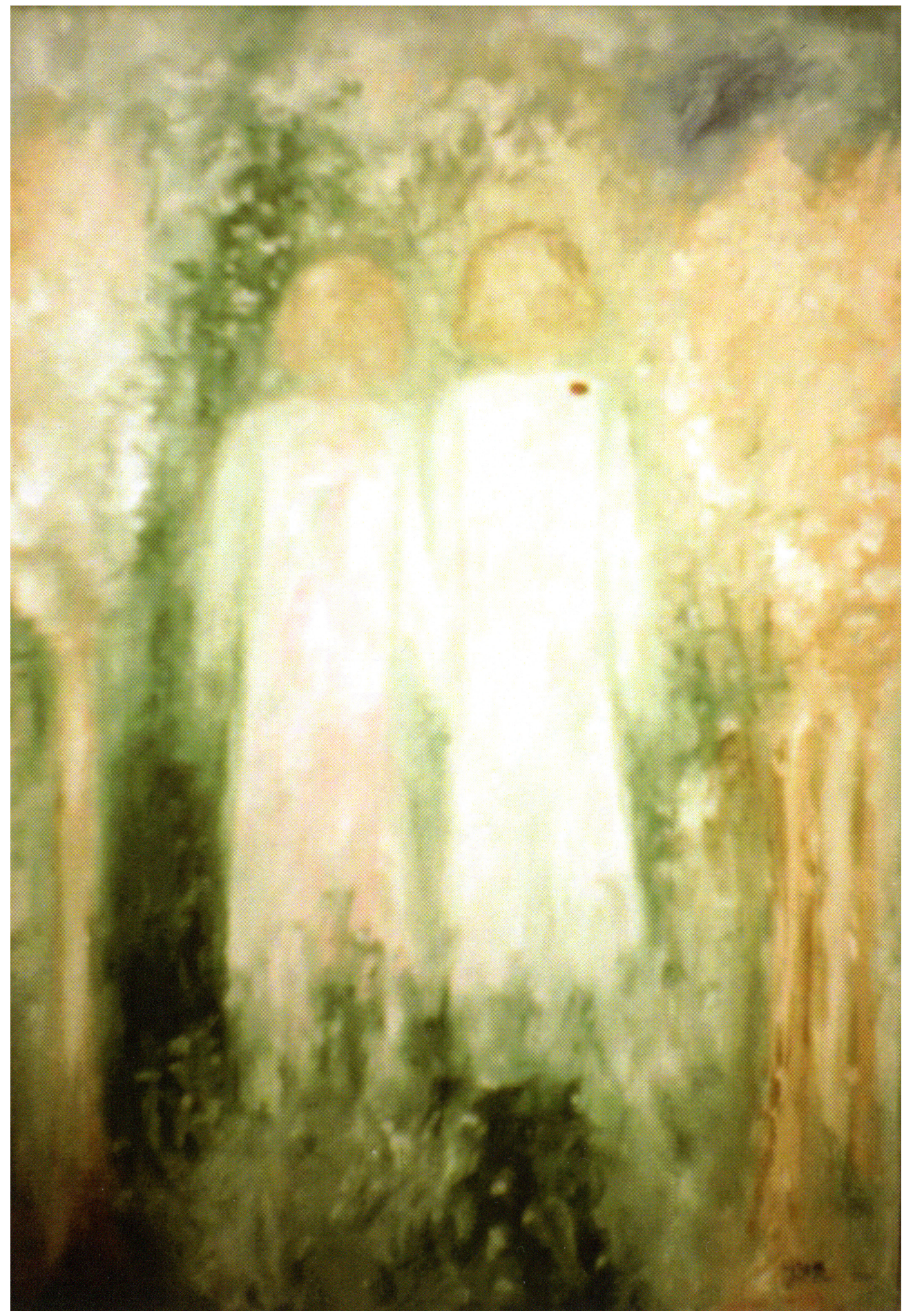

Ilustracja 1. Joanna Ślósarska, Anioły i biedronki na spacerze (olej na płótnie, $120 \times 70 \mathrm{~cm}$ ) Źródło: Ślósarska, 2016a: 32. 
We wstępie do części prezentującej wymiary obrazowania jako element kognitywistycznej teorii języka Langacker zastrzega, że mimo iż „wielu niedoinformowanych” uważa inaczej, „gramatyka kognitywna nie twierdzi, że wszystkie znaczenia zasadzają się na percepcji wzrokowej czy przestrzennej" (Langacker, 2009: 85, podkreślenie w oryginale). Ryzykując zarzut „niedoinformowania”, chciałabym powyższe rozważania zakończyć stwierdzeniem, że analogie między widzeniem malarza (i odbiorcy obrazu), widzeniem poety (i czytelnika poezji) oraz widzeniem teoretyka języka są być może głębsze, niż mogłoby się wydawać adeptom teorii Langackera.

\section{Bibliografia}

Lakoff G. (1989), The Invariance Hypothesis: Do Metaphors Preserve Cognitive Typology?, Duisburg: Linguistic Agency University of Duisburg. Series A., no. 266.

Langacker R.W. (1991), Concept, Image and Symbol, Berlin: Mouton de Gruyter.

Langacker R.W. (2009), Gramatyka kognitywna. Wprowadzenie, przeł. zespół, Kraków: Wydawnictwo Universitas.

Przyboś J. (2016), Przedmowa, [w:] W. Strzemiński, Teoria widzenia, Łódź: Muzeum Sztuki w Łodzi, s. 43-50.

Strzemiński W. (2016), Teoria widzenia, Łódź: Muzeum Sztuki w Łodzi.

Ślósarska J. (1996), Geo-metria, Łódź: Wydawnictwo Biblioteka.

Ślósarska J. (1999), Czekanie na schodach, Łódź: Stowarzyszenie Literackie im. K.K. Baczyńskiego.

Ślósarska J. (2016a), Lśnienie dźwięków, Łódź: Wydawnictwo Primum Verbum.

Ślósarska J. (2016b), Rebis. Wiersze wybrane, Łódź: Wydawnictwo Primum Verbum.

Tabakowska E. (2018), Bez czasowników: starsza pani od gramatyki czyta poezję Joanny Ślósarskiej, [w:] M. Bartosiak, G. Habrajska (red.), Nauka (płynąca ze) sztuki - sztuka (uprawiania) nauki, Łódź: Wydawnictwo Primum Verbum, s. 39-46.

Tabakowska E., Komunikat jako obraz rzeczywistości w jej momentalnych, znikliwych przejawach [w druku]. 